\title{
СИНЕРГЕТИЧНИЙ ПІДХІД ДО ПРОЦЕСУ ПРОФЕСІЙНОЇ ПІДГОТОВКИ МАЙБУТНІХ ВИХОВАТЕЛІВ ДО ФОРМУВАННЯ ЕКОЛОГІЧНО ДОЦІЛЬНОЇ ПОВЕДІНКИ У ДІТЕЙ ДОШКІЛЬНОГО ВІКУ
}

\author{
Сабіна Іванчук \\ кандидат педагогічних наук, доцент кафедри дошкільної освіти \\ ДВНЗ «Донбаський державний педагогічний університет» \\ м. Слов'янськ, Україна \\ ORCID ID 0000-0002-9655-0634 \\ ivanchuk.sabina@gmail.com
}

\begin{abstract}
Анотація. Розвиток екологічної освіти має відбуватись на основі синтезу трьох основних підходів (тенденцій), що сьогодні існують: тенденції формування сучасних екологічних уявлень, тенденції формування принципово нового ставлення до природи i тенденції формування нових стратегій і технологій взаємодії з природою. У статті розкрито особливості синергетичного підходу до процесу професійної підготовки майбутніх вихователів до формування екологічно доцільної поведінки у дітей дошкільного віку. Означені сутнісні характеристики систем за синергетичними уявленнями. Наголошено на базові якості синергетичного підходу, налаштовані саме на екологізацію фахової підготовки студентів у вказаному напрямі. Зроблено висновок, що синергетичний підхід має свою специфіку, істотно збагачує методологію педагогічних досліджень, проте не вичерпує всього iii багатства та багатовимірності.
\end{abstract}

Ключові слова: синергетичний підхід; екологічно доцільна поведінка; підготовка майбутніх вихователів.

Постановка проблеми у загальному вигляді. Згідно 3 концепцією екологічної освіти в Україні стратегічним завданням $є$ формування поколінь із новою екологічною культурою, новим екологічним світоглядом на принципах гуманізму, екологізації мислення, міждисциплінарної інтеграції, історизму та системності в контексті збереження та відновлення природи України та ii біологічного різноманіття; розробка й постійне вдосконалення Державних стандартів професійної екологічної освіти та переробка чинних стандартів усіх рівнів і напрямів підготовки фахівців, виховання дітей та молоді з урахуванням вимог щодо формування екологічної культури.

Аналіз останніх досліджень і публікацій. У загальній інтерпретації методологія означає універсальний інструментарій наукового пізнання певного явища. У педагогічній науці методологія визначає ту чи ту систему принципів, способів організації, побудови теоретичної та практичної діяльності; учення про основи пізнання й перетворення педагогічної дійсності. Методологічні засади

(c) ДВНЗ «Донбаський державний педагогічний університет» 
конкретизуються у вигляді педагогічних парадигм, підходів, концепцій, систем, технологій (С. Гончаренко, Д. Горський, $\quad$ В. Журавльов, В. Краєвський, I. Лернер, А. Хуторський та ін.).

Проблематика синергетичного підходу цікавила багатьох дослідників: В. Андрущенко, В. Аршинов, В. Буданов, О. Вознюк, Н. Гузій, Є. Князєва, І. Кудрявцев, С. Курдюмов, В. Кремень, Н. Сегеда, Л. Ткаченко, С. Ямбург та ін. Мета статті - визначення сутності та характерних особливостей синергетичного підходу в контексті професійної підготовки майбутніх вихователів до формування екологічно доцільної поведінки в дітей дошкільного віку.

Результати дослідження. Новітнім досягненням теорії систем $є$ синергетичний підхід до розвитку та перетворення складних систем.

Поведінка системи багато в чому визначається поведінкою її елементів. Синергетика як універсальна світоглядна наука та напрям міждисциплінарних досліджень вивчає закони та механізми самоорганізації складних систем, скеровує увагу на взаємодію елементів системи з позиції взаємозв'язку складних та відкритих систем, що перебувають у постійному процесі саморозвитку завдяки природній здатності нових систем до самоорганізації (Філософський енциклопедичний словник). 3 позиції синергетики, всі системи містять підсистеми, що постійно змінюються під впливом флуктуацій та біфуркацій (тобто випадкових відхилень та роздвоєнь - точок виникнення нових структур). Побудовані так нові системи $є$ більш сильними, диференційованими, упорядкованими (дисипативними) структурами, яким притаманні певні особливості: когерентність, мінливість, конструктивний хаос, пам'ять структури, взаємозв'язок необхідності та випадковості, неврівноваженість, час функціонування, або незворотність процесів у цих системах (Філософський енциклопедичний словник; Князєва, 2010; Пригожин, 1986; Хакен, 2000). Здобутки синергетики призвели до відмови від лінійних (закритих) систем на користь нелінійних (відкритих), самоорганізованих, що потребують пильного вивчення.

Оскільки завдання синергетики полягає в пошуку законів еволюції та самоорганізації світу, еволюції складних систем, таких як, наприклад, природні та соціальні, фахова підготовка майбутніх вихователів до формування екологічно доцільної поведінки дошкільників цілком логічно пов'язана із включенням в освітній процес синергетичних уявлень про цілісність та взаємозв'язок природи, людини й соціуму.

Професіоналізм педагога: теоретичні й методичні аспекти. - Вип. 14 (Ч. 1). - Слов’янськ, 2021. 
Ситуація, яку простежуємо в сучасному освітньому просторі загалом, описується також через терміни синергетики, про що свідчать наукові доробки вчених (Буданов, 1996; Кремень, 2012; Князєва, 2010). Феномен синергетики широко використовується як можливість нового методологічного рішення актуальних освітніх проблем, особливо в контексті появи суспільства відкритого типу на підставі гуманістичних ідеалів як головної умови успішного життя людства у XXI столітті, а отже, детермінує ставлення до освіти як до відкритої системи, що набуває принципово нових рис (Кремень, 2012). 3 огляду на ідеї синергетичного підходу відзначимо певні характеристики щодо процесу професійної підготовки майбутніх вихователів до формування екологічно доцільної поведінки дошкільників, і які треба брати до уваги під час обговорення концептуальних засад та реалізації відповідної системи експериментальної роботи.

За синергетичними уявленнями, на фахову підготовку майбутніх вихователів щодо формування екологічно доцільної поведінки дошкільників як складну, відкриту систему, можна екстраполювати такі сутнісні характеристики систем:

1) неоднорідність і значна кількість елементів;

2) властивості окремих елементів і властивості системи емерджентні й до цілого не зводяться;

3) ієрархія системи - наявність декількох рівнів і способів досягнення їх мети, що породжує конфлікти рівнів системи;

4) агрегація - об'єднання декількох параметрів системи в параметри більш високого рівня (параметри більш низького рівня знаходять висвітлення в агрегованих параметрах вищого рівня);

5) багатофункціональність - здатність великої системи до реалізації багатьох функцій у цій структурі, що виявляється у властивостях гнучкості, адаптації, живучості (гнучкість - властивість змінювати мету функціонування залежно від умов функціонування чи стану підсистем; адаптація - зміна мети функціонування зі зміною умов функціонування системи; живучість - здатність змінювати мету функціонування за відмови чи ушкодженні елементів системи);

6) надійність - властивість системи реалізовувати задані функції за певний час і забезпечувати задані параметри якості;

7) безпека системи - здатність не завдавати шкоди технічним об'єктам, персоналу, довкіллю;

8) стійкість - властивість системи виконувати свої функції за умови виходу параметрів зовнішнього середовища за певні обмеження; 
9) вразливість - здатність зазнавати пошкоджень під час впливу зовнішніх і внутрішніх чинників (Гібсон,1988, с. 63-67).

У цьому контексті серед загальних ознак відкритості освітнього процесу (вони прописані у відповідних наукових джерелах - О. Бондаревська, С. Кульневич; О. Брижатий, С. Вітвицька, О. Дубасенюк, В. Ільїн, В. Кремень, С. Курдюмов, В. Цикін та ін..), налаштованого саме на екологізацію фахової підготовки студентів у вказаному напряму, наразі відзначимо як базові такі:

- нелінійність, коли знання та досвід еколого-педагогічної діяльності студентів можуть формуватися не тільки за нормативно визначеною траєкторією, а й виникають спонтанно та суб'єктивно завдяки їх самостійним відкриттям;

- незавершеність та відкритість когнітивного концепту, коли під час опанування екологічними знаннями залишається можливість їх доповнення через власні пошуки та досвід певними смислами, значеннями, цінностями, причому смисл і значущість формування екологічно доцільної поведінки дітей не може нав'язуватися студентам зовні, а потребує їх самоорганізованої роботи та врахування індивідуального досвіду, способу життя тощо;

- особистості викладача та студента як суб'єкти педагогічної взаємодії прагнуть до розвитку своєї суб'єктності, вони є відкритими для постійного вільного обміну смислами екологічних знань, стосунків, порозуміння, досвіду;

- навчальні програми з еколого-педагогічної діяльності задають лише базовий i необхідний орієнтир, загальне ядро, що має доповнюватися та трансформуватися залежно від потреб наявної екологічної ситуації, культурних, етнічних, регіональних особливостей;

- поняття «методика» у традиційному розумінні поступається поняттю «технологія» як більш цілісному, ефективному та м'якому добору орієнтирів, що припускають творчий підхід викладача і студентів в опануванні готовністю до формування екологічно доцільної поведінки дошкільників;

- орієнтація не лише на кінцевий результат (певний рівень готовності студентів), але й на процес їх безпосередньої еколого-педагогічної діяльності завдяки організованого іiі проживання та переживання в процесі набуття відповідного досвіду як у взаємодії з природним довкіллям, так й оволодінні технологіями екологічної освіти дітей дошкільного віку;

- еколого-педагогічна підготовка студенів у сучасному контексті уникає готових «рецептів» знань та зразків поведінки, вона пропонує обговорення різноманітних їх варіантів, звертаючись до природної потреби людини обирати, що $є$ однією з гуманних характеристик внутрішнього світу особистості, 
створюючи умови до самовизначення й самоорганізації через актуалізацію иї внутрішніх ресурсів;

- свобода самовираження та самореалізації особистості в освітньому середовищі, пошук студентами індивідуальної стратегії самовизначення в професії та житті, що позначається на їхній власній екологічній поведінці та можливостях професійного формування такої в дітей дошкільного віку;

- відкритість освітнього процесу передбачає, що взаємодія викладача та студентів відбувається в атмосфері порозуміння, теплоти, єдності, групової підтримки, спільної рефлексії, оцінювання та переживань особистих та групових еко-гуманістичних досягнень, успіху, доробків, досвіду тощо;

- усвідомлення того, що екологічні знання - це феномен непостійний, мінливий, як і людина, вони перебувають у стані неперервного розвитку, чим визначають неабиякі потенційні можливості подальшого розвитку особистості;

- здатність педагогічної системи до якісного стрибка, переходу з одного рівня на інший, що дозволяє за певних умов рухатися до вищих станів у розвитку готовності студентів до формування екологічної поведінки дошкільників;

- у системі підготовки майбутніх вихователів до формування екологічно доцільної поведінки дітей функціональне об'єднання основних іiі адекватних структурних компонентів за умови їх спільної дії має спрацювати на реалізацію кумулятивного ефекту, який, як відомо, не дорівнює простій сумі вихідних складників.

За результатами досліджень Г. Бєлєнької, Л. Зданевич, І. Княжевої, Т. Лесіної, О. Листопада, В. Нестеренко, Ю. Руденко, Т. Танько та ін. синергетичний підхід до фахової підготовки майбутніх вихователів означає іiі розгляд як системи, спроможної до самоорганізації та набуття ознак саморозвитку, реалізується він за умови використання в освітньому процесі таких складників, як орієнтація на педагогічну взаємодію суб'єктів навчання; урахування рівня особистісного розвитку кожного студента в процесі індивідуалізації навчання; інтеграція процесуального та результативного компонентів у процесі формування професійної компетентності; використання у всіх формах освітнього процесу діалогової та полілогової моделей спілкування, багатоваріантних завдань, творчих проєктів; залучення до пошукової та дослідницької діяльності тощо.

Відтак, на підставі синергетичного підходу процес фахової підготовки майбутніх вихователів до формування екологічно доцільної поведінки дітей дошкільного віку розглядаємо як самоорганізовану, відкриту та динамічну систему, функціонування та взаємодія компонентів якої створює умови та сприяє 


\section{С. ІВАНЧУК}

Синергетичний підхід до процесу професійної підготовки майбутніх вихователів до формування екологічно доцільної поведінки у дітей дошкільного віку

саморозвитку та самовдосконаленню студентів як екологічних особистостей, професійно підготовлених до виконання завдань екологічної освіти вихованців. У цьому контексті й викладача, і студента сприймаємо як суб'єктів освітнього процесу, де суб'єктність кваліфікується як відкрита до саморозвитку та самоорганізації система. Сигергетичний підхід принципово змінює функції викладача, бо спрямовує викладацьку діяльність на створення таких умов, щоб студенти опинилися, за К. Роджерсом, у ситуації значущого для них учення, що мобілізує їх внутрішні сили, можливості, здібності до саморозвитку, самопізнання, «пробуджує» внутрішню енергію до особистісних змін (Роджерс, 1997).

Запобігання розриву між рівнем знань майбутніх фахівців про охорону довкілля та реальним свідомим і дбайливим ставленням до нього має стати пріоритетним завданням системи особистісно-професійної підготовки. Й. Пригожин попереджав, що система «людина-культура-природа» перебуває в неврівноваженому стані, вихід 3 якого може бути або катастрофічним, або рухатися в бік гармонії взаємостосунків людини та природи. У наших силах, iз погляду синергетики, як підкреслював А. Урсул, суттєво знизити невизначеність майбутнього й на підставі різних альтернатив та пошукових передбачень виявити низку найбільш реальних тенденцій, на які можна впливати та розумно ними управляти (Пригожин, 1986; Урсул, 2001).

\section{Висновки 3 дослідження і перспективи подальших розвідок у цьому} напрямі. Синергетичний, підхід сприяв розробці та реалізації адекватної системи формування готовності студентів до роботи в досліджуваному напрямі. Як зауважують учені, синергетичний підхід має свою специфіку, істотно збагачує методологію педагогічних досліджень, проте не вичерпує всього іï багатства та багатовимірності (Андреев, 1996).

\section{СПИСОК ВИКОРИСТАНИХ ДЖЕРЕЛ}

1. Андреев, В.И. (1996). Педагогика творческого саморазвития. Инновационныий курс. Казань: Изд-во Казансокого университета.

2. Буданов, В.Г. (1996). Эпоха бифуркаций и синергетика в образовании. Москва.

3. Гибсон, Дж. (1988). Экологический подход к зрительному восприятию. Москва: Прогресс.

4. Князева, Е.Н. \& Курдюмов, С.П. (2010). Основания синергетики: Человек, конструирующий себя и свое будущее. Изд. 3. Москва: КомКнига.

5. Кремень, В.Г. \& Ільїн, В.В. (2012). Синергетика в освіті: контекст людиноиентризму. Київ: Педагогічна думка.

6. Пригожин, И. \& Стенгерс, И. (1986). Порядок из хаоса: Новый диалог человека с природой. Москва: Прогресс.

7. Роджерс, К. (1997). Клиенцентрированная терапия. Киев: Ваклер.

Професіоналізм педагога: теоретичні й методичні аспекти. - Вип. 14 (Ч. 1). - Слов’янськ, 2021. 
Синергетичний підхід до процесу професійної підготовки майбутніх вихователів до формування екологічно доцільної поведінки у дітей дошкільного віку

8. Урсул, А.Д. (2001). Модель опережающего образования: ноосферно-экологический ракурс. Москва: Прогресс-Традиция.

9. Философский энциклопедический словарь. (1989). Москва: Сов. Энциклопедия.

10. Хакен, Г. (2000). Основные понятия синергетики. Многообразие поисков и подходов. Москва: Прогресс-Традиция.

\title{
SYNERGETIC APPROACH TO THE PROCESS OF PROFESSIONAL TRAINING OF FUTURE EDUCATORS FOR THE FORMATION OF ENVIRONMENTALLY PERFORMANCE BEHAVIOR OF PRE-SCHOOL AGE CHILDREN
}

\author{
Sabina Ivanchuk \\ Candidate of Pedagogical Sciences, \\ Associate Professor of Preschool Education Department \\ SHEI "Donbas State Pedagogical University" \\ Sloviansk, Ukraine \\ ORCID ID 0000-0002-9655-0634 \\ ivanchuk.sabina@gmail.com
}

\begin{abstract}
The development of environmental education should be based on a synthesis of three main approaches (trends) that exist today: trends in the formation of modern environmental ideas, trends in the formation of a fundamentally new attitude to nature and trends in new strategies and technologies of interaction with nature. Given the study of the phenomenology of professional training of future educators to form environmentally sound behavior of preschool children, it is necessary to clearly define the methodological approaches to its understanding and feasibility.

The issue of synergetics and synergetic approach has interested many researchers, in particular, philosophers and teachers, including: V. Andrushchenko, V. Arshinov, V. Budanov, O. Voznyuk, N. Guziy, E. Knyazeva, I. Kudryavtsev, S. Kurdyumov, V. Kremen, N. Segeda, L. Tkachenko, E. Yamburg and others.

The article reveals the features of a synergetic approach to the process of professional training of future educators for the formation of environmentally sound behavior in preschool children. The essential characteristics of systems according to synergetic representations are defined. Emphasis is placed on the basic qualities of the synergetic approach, tuned precisely to the greening of professional training of students in this area. It is concluded that the synergetic approach has its own specifics, significantly enriches the methodology of pedagogical research, but does not exhaust all its richness and multidimensionality.

The issues of this article are timely and relevant, as evidenced by the activities of international organizations that promote the greening of education, and documents of regulatory and legal support of environmental education in Ukraine.
\end{abstract} educators.

Key words: synergetic approach; environmentally sound behavior; training of future

\section{REFERENCES}

1. Andreev, V.I. (1996). Pedagogy of creative self-development. An innovative course. Kazan: Publ. Kazan university.

2. Budanov, V.G. (1996). The era of bifurcations and synergetics in education. Moscow.

3. Gibson, J. (1988). Ecological approach to visual perception. Moscow: Progress. 
Синергетичний підхід до процесу професійної підготовки майбутніх вихователів до формування екологічно доцільної поведінки у дітей дошкільного віку

4. Knyazeva, E.N. \& Kurdyumov, S.P. (2010). Foundations of synergetics: A person who constructs himself and his future. Moscow. KomKniga.

5. Kremen, V.H. \& Ilin, V.V. (2012). Synergetics in education: context for people-centrism. Kyiv: Pedagogichna dumka.

6. Prigozhin, I. \& Stengers, I. (1986). Order from chaos: A new dialogue between man and nature. Moscow: Progress.

7. Rodzhers, K. (1997). Client-centered therapy. Kyiv: Vakler.

8. Ursul, A.D. (2001). Model of advanced education: noosphere-ecological perspective. Philosophy of ecological education. Moscow: Progress-Tradicija.

9. Philosophical Encyclopedic Dictionary. (1989). Moscow: Sov. enciklopediya.

10. Haken, G. (2000). Basic concepts of synergetics. A variety of searches and approaches. Moscow: Progress-Tradicija.

Матеріали надійшли до редакції 22.04.2021 р. 